\title{
CONFIRMATORY FAKTOR ANALISIS KEKUATAN DAN KELEMAHAN PEMBENTUKAN LEMBAGA PENERBIT (UMSB PRESS) UNIVERSITAS MUHAMMADIYAH SUMATRA BARAT
}

\author{
Zalzulifa $^{1}$, Nasaruddin ${ }^{2}$, Vini Wela Septiana ${ }^{3}$, Sukwan Hanafi ${ }^{4}$ \\ Email : ${ }^{1)}$ zalzulifa@ gmail.com, ${ }^{2)}$ nasaruddin@ gmail.com, ${ }^{3)}$ viniwela86@gmail.com, \\ ${ }^{4)}$ hanafisukwan@gmail.com
}

\author{
${ }^{1)}$ Politeknik Negeri Media Kreatif, ${ }^{2}$ Sekolah Tinggi Keguruan Dan Ilmu Pendidikan (STKIP) \\ Pancakarya Tangerang, ${ }^{3)}$ Universitas Muhammadiyah Sumatera Barat, ${ }^{4)}$ Afiliasi Penerbit Perguruan \\ Tinggi Muhammadiyah Aisyiah (APPTIMA)
}

\begin{abstract}
Abstrak
Tujuan penelitian adalah ingin menguji faktor - faktor kekuatan dan kelemahan dalam pembentukan lembaga penerbit UMSB Pres. Metode yang digunakan adalah metode kuantitatif yang digunakan untuk meneliti populasi dan sampel tertentu, pengumpulan data menggunakan instrument (angket). Populasi yang digunakan didalam penelitian ini yaitu dosen Universitas Muhammadiyah Sumatera Barat yang berjumlah 160 dosen. Untuk penentuan jumlah sampel pada penelitian ini menggunakan rumus slovin dan diperoleh 157 sampel. Hasil penelitian yaitu tidak terdapat pengaruh yang signifikan faktor pengalaman dosen terhadap faktor kelemahan dengan nilai $t_{\text {hitung }}=1.48 \leq t_{\text {tabel }}=1.64$. dan 2) tidak terdapat pengaruh faktor motivasi dosen terhadap faktor kelemahan dengan $t_{\text {hitung }}=1.47 \leq t_{\text {tabel }}=1.64$. 3) tidak terdapat pengaruh faktor dukungan lembaga terhadap faktor kelemahan dalam pembentukan lembaga penerbit (UMSB Press) Universitas Muhammadiyah Sumatra Barat dengan $t_{\text {hitung }}=1.51 \leq t_{\text {tabel }}=1.64$.
\end{abstract}

Kata Kunci: Faktor pengalaman, Faktor Motivasi, Faktor Dukungan Lembaga, Lembaga Penerbit UMSB Presss.

\begin{abstract}
The purpose of this research is to examine the strengths and weaknesses factors in the formation of UMSB publishing house Pres. The method used is a quantitative method to examine populations and specific samples and data collection using instruments (questionnaire). The population used in this study were 160 lecturers from the Muhammadiyah University of West Sumatra. To determine the number of samples in this study using the Slovin formula and obtained 157 samples. The study results show that there is no significant influence of the lecturer experience factor on the weakness factor with $t$-count $=1.48 \leq$ table $=1.64$. and 2) there is no influence of lecturer motivation factors on the weakness factor with $t$-count $=1.47 \leq t$-table $=1.64 .3)$ there is no influence of institutional support factors on weaknesses in the formation of a publisher (UMSB Press), the Muhammadiyah University of West Sumatra with $t$-count $=1.51 \leq$ table $=1.64$.
\end{abstract}

Keywords: Experience factors, Motivation Factors, Institutional Support Factors, UMSB Publisher Institutions Pres.

\section{PENDAHULUAN}

Faktor yang paling mendasar yang menentukan keberhasilan organisasi adalah masalah faktor sumber daya manusia. Sebab manusia adalah fakor kunci (key factor). Sudah menjadi hukum kausalitas, jika manusia mampu melakukan sesuatu sesuai dengan tujuan organisasi, maka tujuan organisasi tersebut akan tercapai juga. Begitu juga dengan keberadaan lembaga penerbit di lingkungan UMSB (UMSB Press). Sebelum melangkah lebih jauh, yang harus diperhitungkan oleh pihak UMSB dalam merencanakan pembangunan lembaga penerbit UMSB Press adalah faktor kemampuan sumber daya manusia, dalam hal ini Dosen sebagai aset kampus. Lembaga penerbit yang memproduksi buku, ditentukan oleh Dosen sebagai penulis. Namun para dosen di lingkungan internal UMSB tidak luput dari permasalahan berupa kelemahan (weakness) seperti; 1) kesulitan dalam menerbitkan buku; 2) kesulitan dalam menulis buku; 3) kesulitan dalam mencetak buku; 4) kesulitan dalam menerbitkan / mencetak buku dan 5) kesulitan memasarkan buku (sumber: studi pendahulu maret, 2020). Berdasarkan studi pendahulu bulan maret 2020 UMSB (Press) memiliki 23 Faktor kekuatan (strenght) berupa; 1) Pengalaman dosen seperti: a) pengalaman mengajar, b) pengalaman menulis buku; c) pengalaman menulis selain dari buku; d) berbagai jenis buku yang ditulis; e) kuantitas buku yang ditulis. 2) motivasi dosen seperti: a) keinginan dosen terhadap kehadiran lembaga penerbit; b) harapan dosen kehadiran UMSB press; c) reward yang dinginkan dosen kehadiran UMSB Press; d) alasan kuat dosen menulis; e) memiliki keinginan khusus untuk menulis buku; f) Jenis buku yang ingin ditulis di masa yang akan datang; g) kebersediaan jika UMB Press yang mengoptimalkan potensi dosen; h) Pemakai jasa ghost write; g) Tertarik menggunakan jasa layanan UMSB Press. 3) Dukungan lembaga seperti: a) dukungan pengadaan mesin cetak sendiri; b) dukungan keberadaan Call center; c) kebersediaan dosen jika UMB Press mengadakan launcing buku; d) kebersediaan jika UMSB Press melakukan penjualan online; e) hasil tulisan dosen dijual melalui jaringan APPTIMA; f) dukungan lembaga mengikuti pelatihan menulis; g) lembaga mendukung dosen mengikuti pelatihan menulis; h) lembaga memotivasi dosen mengikuti latihan (sumber: studi pendahulu maret, 2020). Faktor kelemahan internal organisasi dapat dipengaruh oleh faktor kekuatan karena faktor kelemahan memiliki keterkaitan atau hubungan dengan faktor kekuatan bahkan keduanya saling mempengaruhi ((Alam, 2018): (Tamara, 2016): (Zia, Semiarty, \& Lita, 2018) 
Pandangan penulis mengenai kelemahan dosen di atas, Dosen adalah manusia dewasa yang memiliki dasar keilmuan yang kuat dan mampu memberikan solusi segala kelemahan-kelemahan tersebut dengan memanfaatkan segala kemampuan, pengalaman, pengetahuan, sikap yang dimiliki oleh dosen itu sendiri. Tinggal bagaimana pola pemberdayaan oleh lembaga penerbit itu sendiri. Oleh karena itu, penulis ingin melakukan penelitian dan menganalisis secara mendalam dengan menggunakan model analisis konfirmatory tentang "faktor kekuatan berupa; pengalaman dosen, motivasi dosen dan dukungan lembaga dan pengaruhnya terhadap faktor kelemahan dalam pembentukan lembaga penerbit (UMSB Press) Universitas Muhammadiyah Sumatra Barat". Berdasarkan permasalahan yang dipaparkan di atas maka penelitian ini hanya menganalisis faktor kekuatan dan pengaruhnya terhadap faktor kelemahan dalam pembentukan lembaga penerbit (UMSB Press) Universitas Muhammadiyah Sumatra Barat.

Dari batasan permasalahan, maka secara spesifik rumusan masalah dalam penelitian yaitu (1) apakah terdapat pengaruh faktor pengalaman dosen terhadap faktor kelemahan dalam pembentukan lembaga penerbit (UMSB Press) Universitas Muhammadiyah Sumatra Barat? (2) apakah terdapat pengaruh faktor motivasi dosen terhadap faktor kelemahan dalam pembentukan lembaga penerbit (UMSB Press) Universitas Muhammadiyah Sumatra Barat? (3) apakah terdapat pengaruh faktor dukungan lembaga terhadap faktor kelemahan dalam pembentukan lembaga penerbit (UMSB Press) Universitas Muhammadiyah Sumatra Barat?

\section{METODE}

Metode yang digunakan adalah metode kuantitatif yaitu metode yang berlandasakan pada filsafat pospositivesme, digunakan untuk meneliti populasi dan sampel tertentu, pengumpulan data menggunakan instrument (angket), analisis data menggunakan statistik dengan tujuan menguji hipotesis yang telah ditetapkan (Sugiyono, 2012)

\section{Populasi dan Sampel}

Populasi sebanyak 160 orang dosen. Teknik sampling dengan probability sampling taraf 0.01 . untuk menentukan besar sampel dengan menggunakan rumus Slovin: $\mathrm{S}^{2}=\mathrm{N}: 1+\mathrm{N}(\mathrm{e})^{2}=160: 1+160(0.01)^{2}=160$ : $1.016=157$. Jadi jumlah sampel sebanyak 157 orang yang diambil secara acak. Pertanyaan kritis, "berapa jumlah sampel yang memadai dengan menggunakan SEM?" Jumlah sampel menggunakan SEM 100-150 sudah dianggap memadai (Haryono, 2014; Austin, 2005; Ghozali, 2008).

\section{Difinisi operasional variabel}

Variabel kelemahan (weakness) sebagai variabel laten endogenous dengan lambang $(\eta)$ diukur melalui 5 variabel kontruk dengan menggunakan skala ordinal seperti dalam tabel berikut:

Tabel 1.

Variabel Kontruk Laten Endogenous

\begin{tabular}{|c|c|l|c|}
\hline & No & \multicolumn{1}{|c|}{ Kontruk } & Lambang \\
\hline Weakness & 1 & $\begin{array}{l}\text { Kesulitan dalam } \\
\text { menerbitkan buku }\end{array}$ & Y1 \\
\cline { 2 - 4 } & 2 & $\begin{array}{l}\text { kesulitan dalam menulis } \\
\text { buku }\end{array}$ & Y2 \\
\cline { 2 - 4 } 3 & $\begin{array}{l}\text { kesulitan dalam } \\
\text { mencetak buku }\end{array}$ & Y3 \\
\cline { 2 - 4 } & 4 & $\begin{array}{l}\text { kesulitan dalam } \\
\text { menerbitkan/ mencetak } \\
\text { buku }\end{array}$ & Y4 \\
\cline { 2 - 4 } & 5 & $\begin{array}{l}\text { kesulitan memasarkan } \\
\text { buku }\end{array}$ & Y5 \\
\hline
\end{tabular}

Kemudian variabel kekuatan (strength) sebagai variabel exogenous dengan lamabang $(\xi)$ diukur melalui
29 variabel kontruk dengan menggunakan skala ordinal seperti dalam tabel berikut:

Tabel 2.

Variabel Kontruk Laten Exogenous

\begin{tabular}{|c|c|c|c|}
\hline Strength & No & Kontruk & Lambang \\
\hline \multirow[t]{6}{*}{$\begin{array}{l}\text { Pengalaman } \\
\text { Ksil }\end{array}$} & 1 & $\begin{array}{ll}\text { Dosen } & \text { yang } \\
\text { berpengalaman } & \\
\text { mengajar } & \end{array}$ & $\mathrm{X} 1$ \\
\hline & 2 & $\begin{array}{lr}\text { Dosen } & \text { Yang } \\
\text { Berpengalaman Menulis }\end{array}$ & $\mathrm{X} 2$ \\
\hline & 3 & $\begin{array}{lll}\begin{array}{l}\text { Jumlah } \\
\text { ditulis }\end{array} & \text { buku yang } \\
\end{array}$ & $\mathrm{X} 3$ \\
\hline & 4 & $\begin{array}{l}\text { Pengalaman dosen } \\
\text { menulis selain dari buku }\end{array}$ & $\mathrm{X} 4$ \\
\hline & 5 & $\begin{array}{l}\text { Jenis buku tulisan Dosen } \\
\text { di UMSB }\end{array}$ & $\mathrm{X} 5$ \\
\hline & 6 & $\begin{array}{llr}\text { Jumlah } & \text { halaman } & \text { buku } \\
\text { yang } & \text { ditulis } & \text { Dosen } \\
\text { UMSB } & & \\
\end{array}$ & $\mathrm{X} 6$ \\
\hline \multirow[t]{9}{*}{$\begin{array}{l}\text { Motivasi } \\
\text { Ksi2 }\end{array}$} & 7 & $\begin{array}{l}\text { Keinginan } \quad \text { dosen } \\
\text { terhadap kehadiran } \\
\text { lembaga penerbit }\end{array}$ & $\mathrm{X} 7$ \\
\hline & 8 & $\begin{array}{l}\text { Motivasi dosen } \\
\text { kehadiran UMSB Press }\end{array}$ & $\mathrm{X} 8$ \\
\hline & 9 & $\begin{array}{l}\text { Reward yang dinginkan } \\
\text { dosen kehadiran UMSB } \\
\text { Press }\end{array}$ & $\mathrm{X} 9$ \\
\hline & 10 & $\begin{array}{lll}\begin{array}{l}\text { Alasan } \\
\text { menulis }\end{array} & \text { kuat } & \text { dosen } \\
\end{array}$ & $\mathrm{X} 10$ \\
\hline & 11 & $\begin{array}{l}\text { Memiliki keinginan } \\
\text { khusus menulis buku }\end{array}$ & $\mathrm{X} 11$ \\
\hline & 12 & $\begin{array}{l}\text { Jenis buku yang ingin } \\
\text { ditulis di masa yang } \\
\text { akan datang }\end{array}$ & $\mathrm{X} 12$ \\
\hline & 13 & $\begin{array}{l}\text { Kebersediaan jika UMB } \\
\text { Press yang } \\
\text { mengoptimalkan potensi } \\
\text { dosen }\end{array}$ & $\mathrm{X} 13$ \\
\hline & 14 & Pemakai jasa ghost write & $\mathrm{X} 14$ \\
\hline & 15 & $\begin{array}{l}\text { Tertarik menggunakan } \\
\text { jasa layanan UMSB } \\
\text { Press }\end{array}$ & $\mathrm{X} 15$ \\
\hline \multirow{8}{*}{$\begin{array}{l}\text { Dukungan } \\
\text { lembaga } \\
\text { Ksi3 }\end{array}$} & 16 & $\begin{array}{l}\text { Dukungan pengadaan } \\
\text { mesin cetak sendiri }\end{array}$ & $\mathrm{X} 16$ \\
\hline & 17 & $\begin{array}{ll}\text { Dukungan } & \text { keberadaan } \\
\text { Call center } & \\
\end{array}$ & $\mathrm{X} 17$ \\
\hline & 18 & $\begin{array}{l}\text { Kebersediaan dosen jika } \\
\text { UMB Press mengadakan } \\
\text { launcing buku }\end{array}$ & $\mathrm{X} 18$ \\
\hline & 19 & $\begin{array}{l}\text { Kebersediaan jika } \\
\text { UMSB Press melakukan } \\
\text { penjualan online }\end{array}$ & X19 \\
\hline & 20 & $\begin{array}{l}\text { Hasil tulisan dosen } \\
\text { dijual melalui jaringan } \\
\text { APPTIMA }\end{array}$ & $\mathrm{X} 20$ \\
\hline & 21 & $\begin{array}{lr}\begin{array}{l}\text { Dukungan } \\
\text { mengikuti }\end{array} & \text { lembaga } \\
\text { menulis } & \text { pelatihan } \\
\end{array}$ & $\mathrm{X} 21$ \\
\hline & 22 & $\begin{array}{l}\text { Lembaga mendukung } \\
\text { dosen mengikuti } \\
\text { pelatihan menulis }\end{array}$ & $\mathrm{X} 22$ \\
\hline & 23 & $\begin{array}{l}\text { Lembaga memotivasi } \\
\text { dosen mengikuti latihan }\end{array}$ & $\mathrm{X} 23$ \\
\hline
\end{tabular}

\section{Analisis data}

Analisis data terdiri dari; a) uji validitas dan realibilitas kontruk; b) uji kesesuaian model (CFA); c) uji Construct Reliability (CR), Variance extracted (VE); d) uji hipotesis pengaruh variabel exogenous terhadap variabel endogenous. 


\section{HASIL DAN PEMBAHASAN}

Berdasarkan hasil temuan mengenai faktor-faktor kekuatan dan kelemahan yang mendukung keberadaan lembaga penerbit UMSB Press dari hasil angket diperoleh diperoleh beberapa informasi.

\section{Validitas dan Realibiltas Instrument}

Uji validitas dan realibilitas kontruk faktor kekuatan dan kelemahan dengan menggunakan angket, yang mana sertiap item pertanyaan yang diperoleh dikorelasikan dengan skor total. Hasilnya disajikan pada tabel berikut:

Tabel 3

Hasil Validitas dan Realibiltas Pengalaman Dosen

\begin{tabular}{|c|c|c|c|c|c|}
\hline Eta & $\begin{array}{l}\text { Scale Mean } \\
\text { if Item } \\
\text { Deleted } \\
\end{array}$ & $\begin{array}{c}\text { Scale } \\
\text { Variance if } \\
\text { Item Deleted }\end{array}$ & $\begin{array}{l}\text { Corrected Item- } \\
\text { Total } \\
\text { Correlation } \\
\end{array}$ & $\begin{array}{c}\text { Squared } \\
\text { Multiple } \\
\text { Correlation } \\
\end{array}$ & $\begin{array}{l}\text { Cronbach's } \\
\text { Alpha if Item } \\
\text { Deleted }\end{array}$ \\
\hline $\mathrm{Y} 1$ & 8.3654 & 22.233 & 0.704 & 0.549 & 0.849 \\
\hline $\mathrm{Y} 2$ & 7.9679 & 18.263 & 0.708 & 0.524 & 0.833 \\
\hline $\mathrm{Y} 3$ & 7.9551 & 16.469 & 0.776 & 0.616 & 0.816 \\
\hline Y4 & 8.4872 & 22.316 & 0.685 & 0.536 & 0.852 \\
\hline $\mathrm{Y} 5$ & 7.7885 & 15.639 & 0.749 & 0.579 & 0.831 \\
\hline $\begin{array}{c}\mathrm{ksi} \\
1\end{array}$ & $\begin{array}{l}\text { Scale Mean } \\
\text { if Item } \\
\text { Deleted }\end{array}$ & $\begin{array}{c}\text { Scale } \\
\text { Variance if } \\
\text { Item Deleted }\end{array}$ & $\begin{array}{c}\text { Corrected Item- } \\
\text { Total } \\
\text { Correlation } \\
\end{array}$ & $\begin{array}{c}\text { Squared } \\
\text { Multiple } \\
\text { Correlation }\end{array}$ & $\begin{array}{l}\text { Cronbach's } \\
\text { Alpha if Item } \\
\text { Deleted }\end{array}$ \\
\hline $\mathrm{X} 1$ & 8.6051 & 14.638 & 0.119 & 0.115 & 0.878 \\
\hline $\mathrm{X} 2$ & 9.4586 & 10.75 & 0.835 & 0.756 & 0.736 \\
\hline $\mathrm{X} 3$ & 10.051 & 13.318 & 0.554 & 0.403 & 0.801 \\
\hline $\mathrm{X} 4$ & 9.5159 & 11.213 & 0.594 & 0.563 & 0.787 \\
\hline $\mathrm{X} 5$ & 9.5732 & 10.105 & 0.739 & 0.65 & 0.751 \\
\hline X6 & 9.6115 & 10.406 & 0.769 & 0.65 & 0.744 \\
\hline $\begin{array}{c}\text { ksi } \\
2 \\
\end{array}$ & $\begin{array}{l}\text { Scale Mean } \\
\text { if Item } \\
\text { Deleted } \\
\end{array}$ & $\begin{array}{c}\text { Scale } \\
\text { Variance if } \\
\text { Item Deleted }\end{array}$ & $\begin{array}{c}\text { Corrected Item- } \\
\text { Total } \\
\text { Correlation } \\
\end{array}$ & $\begin{array}{c}\text { Squared } \\
\text { Multiple } \\
\text { Correlation } \\
\end{array}$ & $\begin{array}{c}\text { Cronbach's } \\
\text { Alpha if Item } \\
\text { Deleted } \\
\end{array}$ \\
\hline $\mathrm{X} 7$ & 17.1346 & 44.453 & 0.742 & 0.685 & 0.930 \\
\hline $\mathrm{X} 8$ & 16.1667 & 33.172 & 0.81 & 0.762 & 0.949 \\
\hline X9 & 16.8333 & 40.566 & 0.728 & 0.599 & 0.933 \\
\hline $\mathrm{X} 10$ & 17.0833 & 43.909 & 0.729 & 0.712 & 0.931 \\
\hline $\mathrm{X} 11$ & 17.1538 & 45.254 & 0.965 & 0.97 & 0.927 \\
\hline $\mathrm{X} 12$ & 17.0192 & 43.387 & 0.727 & 0.591 & 0.931 \\
\hline $\mathrm{X} 13$ & 17.0897 & 44.766 & 0.861 & 0.842 & 0.928 \\
\hline $\mathrm{X} 14$ & 17.1346 & 45.111 & 0.856 & 0.837 & 0.929 \\
\hline $\mathrm{X} 15$ & 17.141 & 45.128 & 0.937 & 0.926 & 0.927 \\
\hline $\begin{array}{c}\text { ksi } \\
3\end{array}$ & $\begin{array}{l}\text { Scale Mean } \\
\text { if Item } \\
\text { Deleted }\end{array}$ & $\begin{array}{c}\text { Scale } \\
\text { Variance if } \\
\text { Item Deleted }\end{array}$ & $\begin{array}{c}\text { Corrected Item- } \\
\text { Total } \\
\text { Correlation } \\
\end{array}$ & $\begin{array}{c}\text { Squared } \\
\text { Multiple } \\
\text { Correlation }\end{array}$ & $\begin{array}{c}\text { Cronbach's } \\
\text { Alpha if Item } \\
\text { Deleted }\end{array}$ \\
\hline X16 & 17.109 & 44.833 & 0.901 & 0.887 & 0.927 \\
\hline $\mathrm{X} 17$ & 17.1218 & 45.088 & 0.902 & 0.928 & 0.928 \\
\hline $\mathrm{X} 18$ & 3.1274 & 1.099 & 0.906 & 0.825 & 0.936 \\
\hline X19 & 3.1338 & 1.155 & 0.894 & 0.801 & 0.945 \\
\hline $\mathrm{X} 20$ & 3.1401 & 1.108 & 0.920 & 0.847 & 0.925 \\
\hline $\mathrm{X} 21$ & 5.4088 & 4.914 & 0.851 & 0.783 & 0.932 \\
\hline $\mathrm{X} 22$ & 5.6792 & 6.143 & 0.946 & 0.896 & 0.937 \\
\hline $\mathrm{X} 23$ & 5.3459 & 4.645 & 0.889 & 0.83 & 0.921 \\
\hline
\end{tabular}

Berdasarkan outout SPSS. 22 dari enam item yang digunakan untuk mengukur pengalam dosen diperoleh lima item yang diterima sementara item X1 (Dosen yang berpengalaman mengajar) memiliki nilai correlasi $\mathrm{r}_{\text {hitung }}$ sebesar 0.119 sementara $\mathrm{r}_{\text {tabel }}$ dengan $\mathrm{db}: \mathrm{n}-2=157-2=$ 155 dan nilai $\alpha 0.05=0.156$. karena rhitung $=0.119 \leq$ 0.155 sehingga item tersebut didrop dan tidak digunakan untuk penelitian selanjutnya. Dan nilai Cronbach's Alpha secara keseluruhan $\geq 0$. 600. Sehingga kelima item tersebut memiliki nilai Reliability yang bisa diterima.

\section{CFA Variabel Endogenous}

Confirmatory faktor analisis varaibel endogen berupa hambatan dalam pembentukan UMSB Press diukur dengan 5 variabel kontruk yaitu: Kesulitan dalam menerbitkan buku (Y1), kesulitan dalam menulis buku (Y2), kesulitan dalam mencetak buku (Y3), kesulitan dalam menerbitkan / mencetak buku (Y4), kesulitan memasarkan buku (Y5). Output LISREL Estimates (Maximum Likelihood) hasil modifikasi model disajikan dalam diagram dan tabel sebagai berikut: 


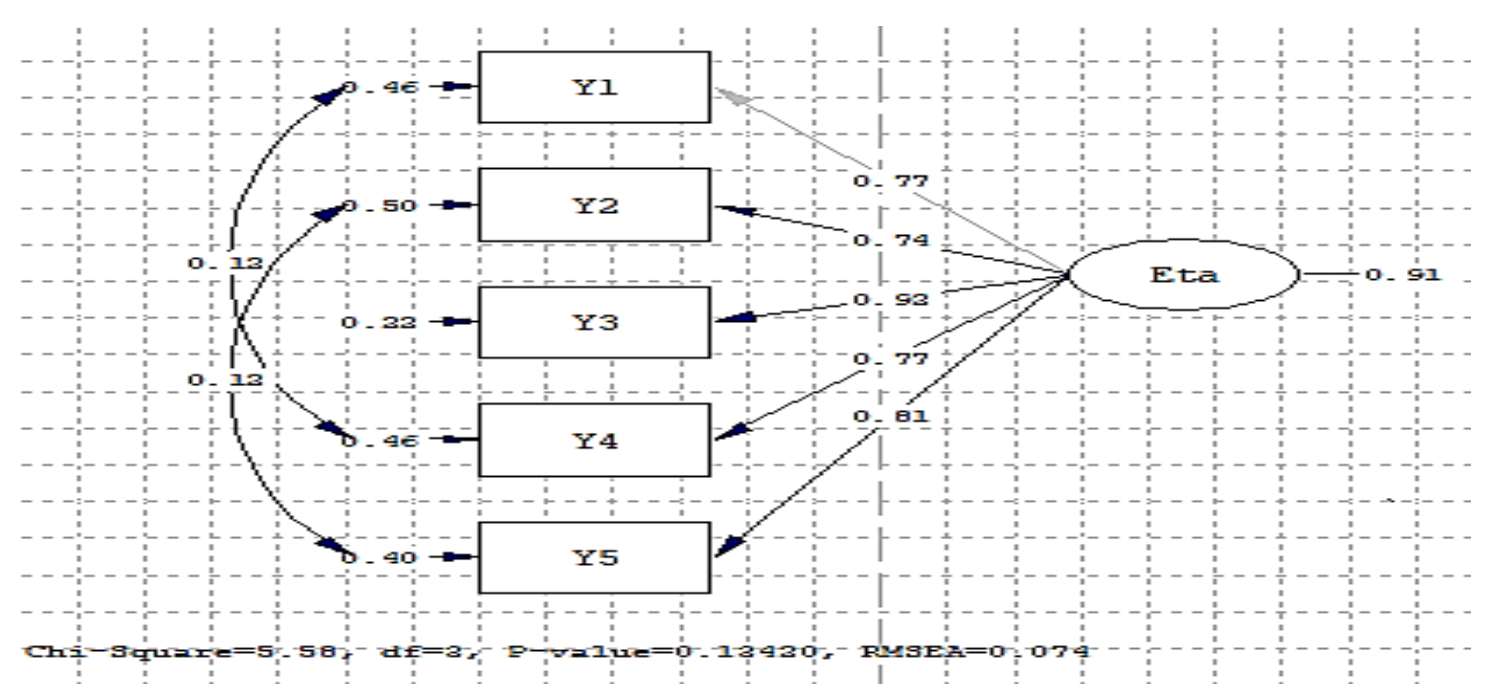

Gambar 1. Diagram Variabel Endogenous

Berdasarkan hasil analisis yang disajikan pada gambar 1, maka dapat diketahui nilai faktor loading untuk setiap indikator konstruk. Dimana masing-masing nilai loading faktor disajikan pada tabel berikut:

Tabel 4.

Muatan Faktor Variabel Endogenous (weakness)

\begin{tabular}{|c|c|c|c|c|c|c|c|}
\hline Kontruk & loading $(\lambda)$ & Error $(\varepsilon)$ & $\mathrm{t}$-value & $\begin{array}{c}\mathrm{t} \text {-tabel } \\
\alpha 0.05: \mathrm{n} \geq 100\end{array}$ & Errorvar & $\mathrm{R}^{\mathbf{2}}$ & Ket \\
\hline $\mathbf{1}$ & $\mathbf{2}$ & $\mathbf{3}$ & $\mathbf{4}$ & $\mathbf{5}$ & $\mathbf{6}$ & $\mathbf{7}$ & $\mathbf{8}$ \\
\hline Y1 & 1 & - & - & - & - & - & Tidak signifikan \\
\hline Y2 & 0.97 & 0.10 & 9.39 & 1.64 & 0.45 & 0.55 & Signifikan \\
\hline Y3 & 1.11 & 0.10 & 10.82 & 1.64 & 0.28 & 0.72 & Signifikan \\
\hline Y4 & 0.98 & 0.10 & 9.55 & 1.64 & 0.43 & 0.57 & Signifikan \\
\hline Y5 & 1.03 & 0.10 & 10.07 & 1.64 & 0.37 & 0.63 & Signifikan \\
\hline
\end{tabular}

Hasil perhitungan dengan bantuan aplikasi LISREL pada tabel 4 di atas diperoleh nilai faktor loading atau koefisien korelasi pada kolom 2, error pada kolom 3 thitung pada kolom 4 t tabel pada kolom 5 erorvarian pada kolom 6 dan koefisien determinan pada kolom7. Untuk Goodness of Fit Statistics disajikan dalam tabel berikut:

Tabel 5

Good of Fit Index Variabel Endogenous

\begin{tabular}{|c|l|c|c|l|}
\hline No & Good Of Fit Index & Observasi Model & Cut Off -Value & Criteria \\
\hline 1 & df = Degrees Of Freedom & 3 & $>0$ & Identified \\
\hline 2 & Chi-Square & 5.58 & $10-2: 0,05: \mathrm{df} \leq$ & Good Fit \\
\hline 3 & p-value & 0.14 & $>0.05$ & Good fit \\
\hline 4 & RMSEA & 0.07 & $\leq 0,08$ & Good Fit \\
\hline 5 & ECVI & 0.19 & $\leq 0.05$ & Marginal Fit \\
\hline 6 & CAIC & 78.25 & $\geq 0.05$ & Good Fit \\
\hline 7 & RMR & 0.01 & $\leq 0.05$ & Good fit \\
\hline 8 & Standardized RMR & 0.01 & $\geq 0.10$ & Good Fit \\
\hline 9 & GFI & 0.99 & $\geq 0.95$ & Good Fit \\
\hline 10 & AGFI & 0.93 & $\geq 0.05$ & Good Fit \\
\hline 11 & PGFI & 0.20 & $\geq 0.90$ & Good Fit \\
\hline 12 & CFI & 1.00 & $\geq 0.90$ & Good Fit \\
\hline 13 & TLI atau NNFI & 0.99 & & \\
\hline
\end{tabular}

\section{Hipotesis fundamental}

Ho: $\boldsymbol{\Sigma} \neq \boldsymbol{\Sigma}(\boldsymbol{\theta})=$ tidak terdapat perbedaan yang signifikan antara model teori yang diusulkan dengan model empiris hasil pengamatan.

$\mathbf{H}_{1}: \boldsymbol{\Sigma}=\boldsymbol{\Sigma}(\boldsymbol{\theta})=$ terdapat perbedaan yang signifikan antara model teori yang diusulkan dengan model empiris hasil pengamatan.

Berdasarkan hasil uji Goodness of Fit Statistics diatas di atas diperoleh rata-rata model yang fit, dengan demikian Ho diterima. Artinya tidak terdapat perbedaan yang signifikan antara model teori yang diusulkan dengan model empiris hasil pengamatan.
Hasil peneltian membuktikan bahwa variabel kontruk Y1 Y2 Y3 Y4 Y5 dapat mengukur variabel kelemahan (Weakness) dalam pembentukan lembaga penerbit UMSB Press

\section{CFA Variabel Exogenous}

Confirmatory faktor analisis varaibel exogen berupa faktor kekuatan (strength) dalam pembentukan UMSB Press diukur dengan 3 variabel laten yaitu: pengalaman dosen $(\xi 1)$ dengan kontruk yaitu X2 - X6, motivasi dosen $(\xi 2)$ dengan kontruk X7 - X15 dan dukungan lembaga ( 33 ) dengan kontruk X16-X23. Output LISREL Estimates (Maximum Likelihood) hasil modifikasi model disajikan dalam diagram dan tabel sebagai berikut: 


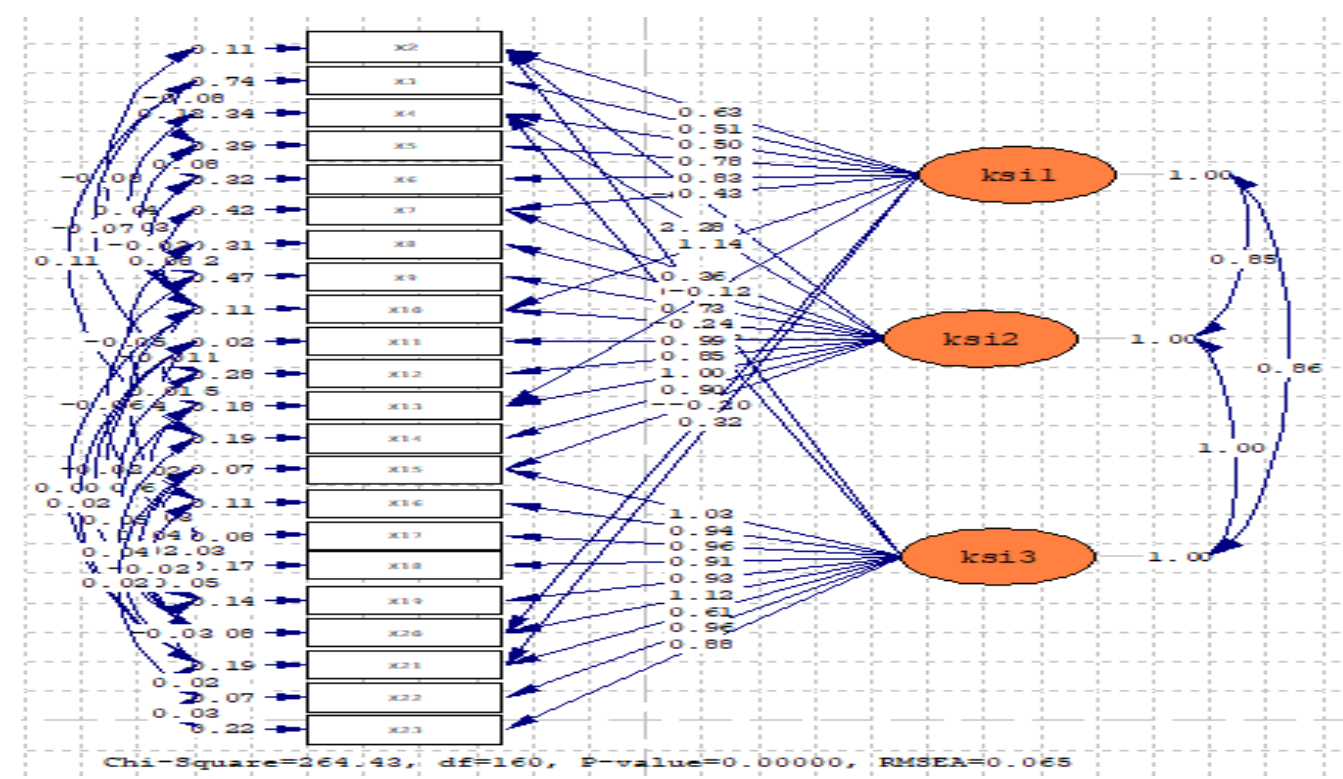

Gambar 2. Diagram variabel exogenous

Berdasarkan hasil analisis yang disajikan pada gambar 1, maka dapat diketahui nilai faktor loading untuk setiap indikator konstruk. Dimana masing-masing nilai loading faktor disajikan pada tabel berikut:

Tabel 5

Muatan Faktor Variabel Exogenous (Strength)

\begin{tabular}{|c|c|c|c|c|c|c|c|c|}
\hline Strenght & Kontruk & loading $(\lambda)$ & Error $(\varepsilon)$ & $\mathrm{t}$-value & $\begin{array}{c}t \text {-tabel } \\
\alpha 0.05: n \geq 100\end{array}$ & Errorvar & $\mathrm{R}^{2}$ & Ket \\
\hline 1 & 2 & 3 & 4 & 5 & 6 & 7 & 8 & 9 \\
\hline \multirow{5}{*}{$\begin{array}{l}\text { pengalama } \\
\mathrm{n} \text { dosen } \\
(\xi 1)\end{array}$} & $\mathrm{X} 2$ & 0.80 & 0.12 & 6.66 & 1.64 & 0.07 & 0.93 & Signifikan \\
\hline & $\mathrm{X} 3$ & 0.49 & 0.07 & 6.53 & 1.64 & 0.73 & 0.25 & Signifikan \\
\hline & $\mathrm{X} 4$ & 0.41 & 0.13 & 3.15 & 1.64 & 0.37 & 0.63 & Signifikan \\
\hline & $\mathrm{X} 5$ & 0.76 & 0.07 & 10.85 & 1.64 & 0.42 & 0.58 & Signifikan \\
\hline & $\mathrm{X} 6$ & 0.80 & 0.06 & 13.33 & 1.64 & 0.36 & 0.64 & Signifikan \\
\hline \multirow{9}{*}{$\begin{array}{c}\text { motivasi } \\
\text { dosen }(\xi 2)\end{array}$} & $\mathrm{X} 7$ & 0.37 & 0.13 & 2.92 & 1.64 & 0.43 & 0.57 & Signifikan \\
\hline & $\mathrm{X} 8$ & 0.83 & 0.06 & 12.86 & 1.64 & 0.31 & 0.69 & Signifikan \\
\hline & X9 & 0.73 & 0.06 & 10.65 & 1.64 & 0.45 & 0.54 & Signifikan \\
\hline & $\mathrm{X} 10$ & 1.27 & 0.28 & 4.56 & 1.64 & 0.05 & 0.94 & Signifikan \\
\hline & $\mathrm{X} 11$ & 0.99 & 0.05 & 17.57 & 1.64 & 0.01 & 0.99 & Signifikan \\
\hline & $\mathrm{X} 12$ & 0.65 & 0.04 & 13.32 & 1.64 & 0.16 & 0.73 & Signifikan \\
\hline & $\mathrm{X} 13$ & 1.00 & 0.09 & 10.62 & 1.64 & 0.18 & 0.82 & Signifikan \\
\hline & $\mathrm{X} 14$ & 0.90 & 0.06 & 14.78 & 1.64 & 1.19 & 0.81 & Signifikan \\
\hline & $\mathrm{X} 15$ & 0.09 & 0.28 & 0.33 & 1.64 & 0.07 & 0.93 & Tidak signifikan \\
\hline \multirow{8}{*}{$\begin{array}{c}\text { dukungan } \\
\text { lembaga } \\
(\xi 3)\end{array}$} & $\mathrm{X} 16$ & 0.95 & 0.05 & 16.46 & 1.64 & 0.11 & 0.89 & Signifikan \\
\hline & $\mathrm{X} 17$ & 0.96 & 0.05 & 16.46 & 1.64 & 0.08 & 0.92 & Signifikan \\
\hline & $\mathrm{X} 18$ & 0.91 & 0.06 & 14.96 & 1.64 & 0.17 & 0.83 & Signifikan \\
\hline & X19 & 0.92 & 0.06 & 15.41 & 1.64 & 0.14 & 0.86 & Signifikan \\
\hline & $\mathrm{X} 20$ & 0.19 & 0.06 & 3.07 & 1.64 & 0.08 & 0.91 & Tidak signifikan \\
\hline & $\mathrm{X} 21$ & 0.44 & 0.08 & 5.11 & 1.64 & 0.16 & 0.83 & Signifikan \\
\hline & $\mathrm{X} 22$ & 0.96 & 0.05 & 16.50 & 1.64 & 0.07 & 0.93 & Signifikan \\
\hline & $\mathrm{X} 23$ & 0.88 & 0.06 & 14.04 & 1.64 & 0.23 & 0.77 & Signifikan \\
\hline
\end{tabular}

Hasil perhitungan dengan bantuan aplikasi lisrel pada tabel 4 di atas diperoleh nilai faktor loading atau koefisien korelasi pada kolom 3, error pada kolom 4, $\mathrm{t}_{\text {hitung }}$ pada kolom 5 , $\mathrm{t}_{\text {tabel }}$ pada kolom 6 erorvarian pada kolom 7 dan, koefisien determinan pada kolom 8 . Kontruk $X_{15}$ untuk mengukur motivasi dosen ( $(\xi 2)$ memiliki nilai standar loading yang tidak signifikan sebasar 0.09, namun berdasarkan hasil modifikasi model memiliki nilai standar loading yang signifikan sebesar 0.87 untuk mengukur dukungan lembaga ( $(3)$.
Besarhubungan timbal balik antara variabel laten exogenous dapat dilihat dari nilai koefisien phi $(\phi)$. Antara $\xi 1$ dengan $\xi 2$ nilai loading $=0.85$, error $=0.04$, $\mathrm{t}$ value $=22.32$, dan antara $\xi 1$ dengan $\xi 3$ nilai loading $=$ 0.86 , error $=0.04, \mathrm{t}$-value $=23.89$. kemudian antara $\xi 2$ dengan $\xi 3$ nilai loading $=1.00$, error $=0.00$, $\mathrm{t}$-value $=$ 341.83. Untuk Goodness of Fit Statistics disajikan dalam tabel berikut: 
Tabel 6

Good Of Fit Index variabel Exogenous (strength)

\begin{tabular}{|c|l|c|c|c|}
\hline No & Good of Fit Index & Observasi Model & Cut Off -Value & Criteria \\
\hline 1 & df = Degrees of Freedom & 59 & $>0$ & Identified \\
\hline 2 & Chi-Square & 288.07 & $46-3: 0,05: \mathrm{df} \geq 59.30$ & Marginal Fit \\
\hline 3 & p-value & 0.00 & $>0.05$ & Marginal Fit \\
\hline 4 & RMSEA & 0.065 & $\leq 0,08$ & Good Fit \\
\hline 5 & ECVI & 3.24 & $\leq 0.05$ & Marginal Fit \\
\hline 6 & CAIC & 827.66 & $\geq 0.05$ & Good Fit \\
\hline 7 & RMR & 0.027 & $\leq 0.05$ & Good fit \\
\hline 8 & Standardized RMR & 0.026 & $\leq 0.10$ & Good Fit \\
\hline 9 & GFI & 0.90 & $\geq 0.90$ & Good Fit \\
\hline 10 & AGFI & 0.79 & $\geq 0.85$ & Marginal Fit \\
\hline 11 & PGFI & 0.55 & $\geq 0.05$ & Good Fit \\
\hline 12 & CFI & 0.99 & $\geq 0.90$ & Good Fit \\
\hline 13 & TLI atau NNFI & 0.99 & $\geq 0.90$ & Good Fit \\
\hline
\end{tabular}

\section{Hipotesis fundamental}

Ho $_{\boldsymbol{O}} \boldsymbol{\Sigma} \neq \boldsymbol{\Sigma}(\boldsymbol{\theta})=$ tidak terdapat perbedaan yang signifikan antara model teori yang diusulkan dengan model empiris hasil pengamatan. $\mathbf{H}_{\mathbf{1}}: \boldsymbol{\Sigma}=\boldsymbol{\Sigma}(\boldsymbol{\theta})=$ terdapat perbedaan yang signifikan antara model teori yang diusulkan dengan model empiris hasil pengamatan.

Berdasarkan hasil uji Goodness of Fit Statistics diatas di atas diperoleh rata-rata model yang fit, meskipun ada sebagian yang memiliki marginal fit, namun seperti yang dinyatakan Jöreskog \& Sörbom (1989) bahwa tidak semua model yang diusulkan dituntut untuk memiliki model fit. Oleh karena itu Ho diterima. Artinya tidak terdapat perbedaan yang signifikan antara model teori yang diusulkan dengan model empiris hasil pengamatan. Hasil peneltian membuktikan bahwa variabel kontruk dari variabel laten pengalaman dosen $(\xi 1)$, motivasi dosen ( $(2)$ dan dukungan lembaga ( $\xi 3$ ) dapat mengukur variabel kekuatan (strenght) dalam pembentukan lembaga penerbit UMSB Press

CFA pengaruh faktor kekuatan terhadap faktor kelemahan (full model)

Confirmatory faktor analisis varaibel exogenous berupa faktor kekuatan (strength) dalam pembentukan UMSB Press diukur dengan 3 variabel laten yaitu: pengalaman dosen ( $\xi 1)$ dengan kontruk yaitu X2 X3 X4 X5 dan X6, motivasi dosen ( $\xi 2)$ dengan kontruk X7 X8 X9 X10 X11 $\mathrm{X} 12 \mathrm{X} 13 \mathrm{X} 14$ dan X15 dan dukungan lembaga $(\xi 3)$ dengan kontruk X16 X17 X18 X19 X20 X21 X22 dan $\mathrm{X} 23$ dan pengaruhnya terhadap faktor kelemahan (weakness) dengan kontruk Y1 Y2 Y3 Y4 dan Y5.

Output LISREL Estimates (Maximum Likelihood) hasil sebelum dan sesudah dimodifikasi model disajikan dalam diagram sebagai berikut:

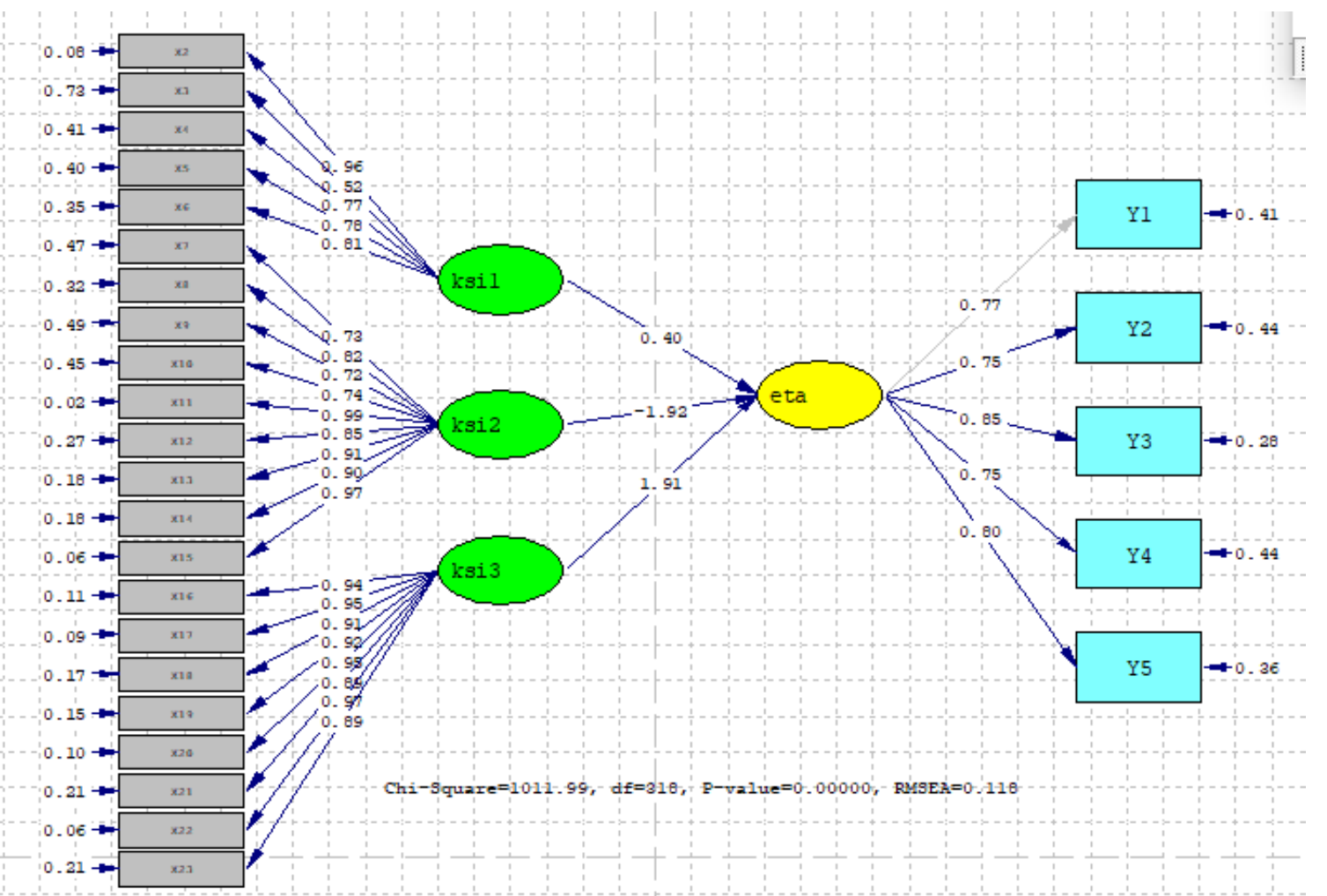

Gambar 4. Full Model Sebelum Modifikasi 


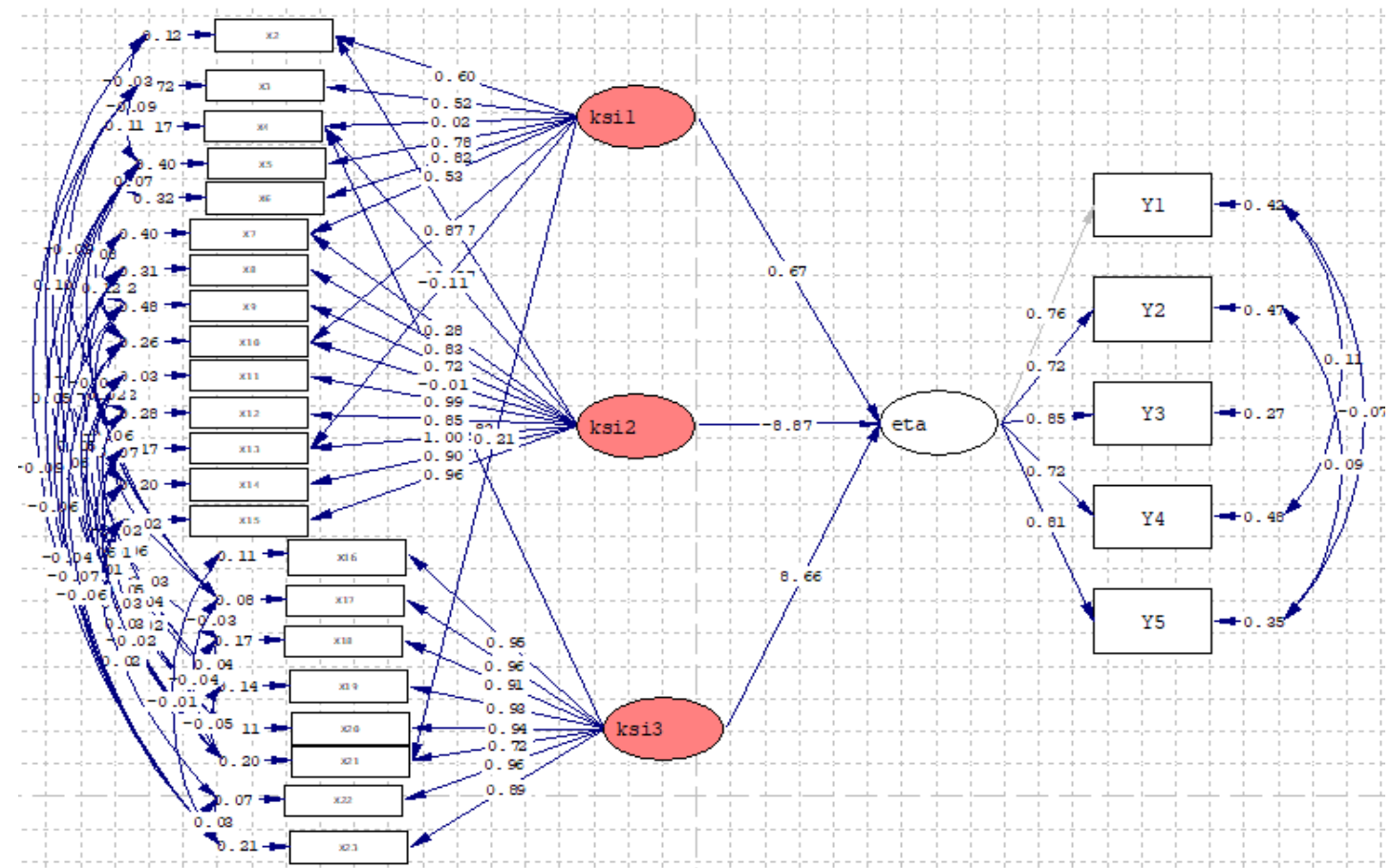

Gambar 5. Full Model Setelah Modifikasi

Berdasarkan hasil analisis yang disajikan pada gambar 1, maka dapat diketahui nilai faktor loading untuk setiap indikator konstruk. Dimana masing-masing nilai loading faktor disajikan pada tabel berikut:

Tabel 7

Muatan Faktor Variabel Exogenous (strength) dan endogen (weakness)

\begin{tabular}{|c|c|c|c|c|c|c|c|c|}
\hline Strenght & Kontruk & loading $(\lambda)$ & $\begin{array}{l}\text { Error } \\
(\varepsilon)\end{array}$ & $\mathrm{t}$-Value & $\begin{array}{c}\mathrm{t} \text {-tabel } \\
\alpha 0.05: \mathrm{n} \geq 100\end{array}$ & Errorvar & $\mathrm{R}^{2}$ & Ket \\
\hline 1 & 2 & 3 & 4 & 5 & 6 & 7 & 8 & 9 \\
\hline \multirow{5}{*}{$\begin{array}{l}\text { Kelemahan } \\
(\eta)\end{array}$} & Y1 & 0.77 & - & - & - & 0.42 & 0.58 & $\mathrm{df}$ \\
\hline & Y2 & 0.73 & 0.08 & 8.53 & 1.64 & 0.47 & 0.53 & Signifikan \\
\hline & Y3 & 0.86 & 0.08 & 9.83 & 1.64 & 0.27 & 0.73 & Signifikan \\
\hline & Y4 & 0.73 & 0.07 & 10.13 & 1.64 & 0.48 & 0.52 & Signifikan \\
\hline & Y5 & 0.81 & 0.09 & 9.05 & 1.64 & 0.35 & 0.65 & Signifikan \\
\hline \multirow{5}{*}{$\begin{array}{l}\text { pengalaman } \\
\text { dosen }(\xi 1)\end{array}$} & $\mathrm{X} 2$ & 0.60 & 0.10 & 5.90 & 1.64 & 0.12 & 0.88 & Signifikan \\
\hline & X3 & 0.51 & 0.07 & 6.92 & 1.64 & 0.68 & 0.28 & Signifikan \\
\hline & $\mathrm{X} 4$ & 0.01 & 0.71 & 0.02 & 1.64 & 0.17 & 0.83 & Tidak Signifikan \\
\hline & $\mathrm{X5}$ & 0.78 & 0.06 & 11.27 & 1.64 & 0.40 & 0.60 & Signifikan \\
\hline & X6 & 0.82 & 0.06 & 12.25 & 1.64 & 0.32 & 0.68 & Signifikan \\
\hline \multirow{9}{*}{$\begin{array}{c}\text { motivasi } \\
\text { dosen }(\xi 2)\end{array}$} & $\mathrm{X7}$ & 0.53 & 0.13 & 3.97 & 1.64 & 0.40 & 0.60 & Signifikan \\
\hline & $\mathrm{X} 8$ & 0.83 & 0.06 & 12.76 & 1.64 & 0.31 & 0.69 & Signifikan \\
\hline & X9 & 0.72 & 0.06 & 10.51 & 1.64 & 0.47 & 0.52 & Signifikan \\
\hline & X10 & 0.86 & 0.13 & 6.73 & 1.64 & 0.25 & 0.74 & Signifikan \\
\hline & $\mathrm{X} 11$ & 0.99 & 0.05 & 17.22 & 1.64 & 0.02 & 0.97 & Signifikan \\
\hline & $\mathrm{X} 12$ & 0.65 & 0.04 & 13.21 & 1.64 & 0.16 & 0.72 & Signifikan \\
\hline & $\mathrm{X} 13$ & 0.11 & 0.07 & 1.51 & 1.64 & 0.17 & 0.83 & Tidak Signifikan \\
\hline & $\mathrm{X} 14$ & 0.90 & 0.06 & 14.48 & 1.64 & 0.20 & 0.80 & Signifikan \\
\hline & $\mathrm{X} 15$ & 0.95 & 0.06 & 15.86 & 1.64 & 0.07 & 0.93 & Signifikan \\
\hline \multirow{8}{*}{$\begin{array}{c}\text { dukungan } \\
\text { lembaga }(\xi 3)\end{array}$} & $\mathrm{X} 16$ & 0.95 & 0.06 & 15.86 & 1.64 & 0.11 & 0.89 & Signifikan \\
\hline & $\mathrm{X} 17$ & 0.96 & 0.05 & 16.29 & 1.64 & 0.08 & 0.92 & Signifikan \\
\hline & $\mathrm{X} 18$ & 0.91 & 0.06 & 14.80 & 1.64 & 0.17 & 0.83 & Signifikan \\
\hline & X19 & 0.93 & 0.06 & 15.34 & 1.64 & 0.14 & 0.86 & Signifikan \\
\hline & $\mathrm{X} 20$ & 0.94 & 0.05 & 15.86 & 1.64 & 0.11 & 0.89 & signifikan \\
\hline & $\mathrm{X} 21$ & 0.21 & 0.08 & 2.44 & 1.64 & 0.20 & 0.80 & Signifikan \\
\hline & $\mathrm{X} 22$ & 0.96 & 0.05 & 16.44 & 1.64 & 0.07 & 0.93 & Signifikan \\
\hline & $\mathrm{X} 23$ & 0.89 & 0.06 & 14.24 & 1.64 & 0.21 & 0.79 & Signifikan \\
\hline
\end{tabular}

Hasil perhitungan dengan bantuan aplikasi lisrel pada tabel 4 di atas diperoleh nilai faktor loading atau koefisien korelasi pada kolom 3, error pada kolom 4, $t_{\text {hitung pada }}$ kolom $5, \mathrm{t}_{\text {tabel }}$ pada kolom 6 erorvarian pada kolom 7 dan, koefisien determinan pada kolom 8. Kontruk kesulitan dalam menerbitkan buku (Y1) untuk mengukur faktor kelemahan $(\eta)$ memiliki nilai standar loading yang tidak signifikan sebasar 0.77 sebagai degree of freedom dari 10 yaitu 5 variabel kontruk ditambah 5 error. Oleh karena itu kontruk tersebut disngkirkan dari model.

Berdasar hasil modifikasi model kontruk keinginan dosen terhadap kehadiran lembaga penerbit (X7) selain digunakan untuk mengukur motivasi dosen ( $(2)$ dapat juga digunakan untuk mengukur pengalaman dosen $(\xi 1)$ dengan nilai koefisien korelasi (loading) sebesar 0.53, error sebesar 0.13, t-value sebesar 3.97. Begitu juga dengan kontruk dukungan lembaga mengikuti pelatihan menulis (X21) dengan nilai koefisien korelasi (loading) sebesar 0.21 error sebesar 0.08 dan t-value sebesar 2.44. Hasil modifikasi diperoleh hubungan timbal balik (Correlation Matrix of Independent Variables) antara variabel laten exogenous dapat dilihat dari nilai koefisien phi $(\phi)$. Antara $\xi 1$ dengan $\xi 2$ nilai loading $=0.86$, error $=$ 0.04 , t-value $=24.33$, dan antara $\xi 1$ dengan $\xi 3$ nilai 
loading $=0.84$, error $=0.04, \mathrm{t}$-value $=22.83$. kemudian antara $\xi 2$ dengan $\xi 3$ nilai loading $=1.00$, error $=0.00$, $\mathrm{t}$ -

value $=1187.20$. Untuk Goodness of Fit Statistics disajikan dalam tabel berikut:

Tabel 8

Good of Fit Index Variabel Exogenous (Strength) dan Endogen (Weakness)

\begin{tabular}{|c|l|c|c|c|}
\hline No & Good of Fit Index & Observasi Model & Cut Off -Value & Criteria \\
\hline 1 & df = Degrees of Freedom & 263 & $>0$ & Identified \\
\hline 2 & Chi-Square & 367.37 & $\begin{array}{c}46-3: 0,05: \mathrm{df} \geq \\
59.30\end{array}$ & Marginal Fit \\
\hline 3 & p-value & 0.00 & $\leq 0.05$ & Good Fit \\
\hline 4 & RMSEA & 0.04 & $\leq 0,08$ & Good Fit \\
\hline 5 & ECVI & 4.85 & $\leq 0.05$ & Marginal Fit \\
\hline 6 & CAIC & 1033.36 & $\geq 0.05$ & Good Fit \\
\hline 7 & RMR & 0.033 & $\leq 0.05$ & Good fit \\
\hline 8 & Standardized RMR & 0.034 & $\leq 0.10$ & Good Fit \\
\hline 9 & GFI & 0.86 & $\geq 0.90$ & Marginal Fit \\
\hline 10 & AGFI & 0.80 & $\geq 0.85$ & Marginal Fit \\
\hline 11 & PGFI & 0.60 & $\geq 0.05$ & Good Fit \\
\hline 12 & CFI & 0.99 & $\geq 0.90$ & Good Fit \\
\hline 13 & TLI atau NNFI & 0.99 & $\geq 0.90$ & Good Fit \\
\hline
\end{tabular}

\section{Hipotesis fundamental}

$\mathbf{H o}_{\mathbf{0}}: \boldsymbol{\Sigma} \neq \boldsymbol{\Sigma}(\boldsymbol{\theta})=$ tidak terdapat perbedaan yang signifikan antara model teori yang diusulkan dengan model empiris hasil pengamatan. $\mathbf{H}_{\mathbf{1}}: \boldsymbol{\Sigma}=\boldsymbol{\Sigma}(\boldsymbol{\theta})=$ terdapat perbedaan yang signifikan antara model teori yang diusulkan dengan model empiris hasil pengamatan.

Berdasarkan hasil uji Goodness of Fit Statistics diatas di atas diperoleh rata-rata model yang fit, meskipun ada sebagian yang memiliki marginal fit, namun seperti yang dinyatakan Joreskog dan Sarbom, (1989) bahwa tidak semua model yang diusulkan dituntut untuk memiliki model fit. Oleh karena itu Ho diterima. Artinya tidak terdapat perbedaan yang signifikan antara model teori yang diusulkan dengan model empiris hasil pengamatan. Hasil penelitian membuktikan bahwa faktor kekuatan (strenght) yang terdiri dari variabel kontruk dari variabel laten pengalaman dosen $(\xi 1)$, motivasi dosen ( $\xi 2)$, dukungan lembaga ( $\xi 3)$ dan faktor kelemahan (weakness) yang terdiri dari kontruk Y2 Y3 Y4 Y5 dapat digunakan dalam pembentukan lembaga penerbit UMSB Press

\section{Construct Reliability (CR), Variance extracted (VE).}

Construct Reliability (CR), Variance extracted (VE). Menurut Haryono S (2014), "realiabilitas adalah ukuran konsisten internal dari indikator-indikator yang digunakan dalam penelitian. Dari hasil perhitungan dari 5 kontruk faktor kelemahan (weakness) diperoleh Construct Reliability (CR) sebagai berikut:

$$
\begin{gathered}
C R=\frac{\left(\sum \lambda_{\mathrm{i}}\right)^{2}}{\left(\sum \lambda_{\mathrm{i}}\right)^{2}+\sum \varepsilon i}=\frac{(3.9)^{2}}{(3.9)^{2}+0.32}=\frac{15.21}{15.53} \\
=0.97
\end{gathered}
$$

Construct Reliability (CR) sebesar $0.97 \geq 0.70$ sebagai cut-off value, sehingga disimpulakan kontruk untuk mengukur faktor kelemahan (weakness) memiliki realibilitas yang stabil. Sedangkan untuk nilai Varian Exracted (VE) sebagai berikut:

$$
V E=\frac{\left(\sum \lambda_{\mathrm{i}}{ }^{2}\right)}{\left(\sum \lambda_{\mathrm{i}}{ }^{2}\right)+\sum \varepsilon i}=\frac{3.05}{3.05+0.32}=\frac{3.05}{3.37}=0.90
$$

Varian Exracted (VE) sebesar $0.90 \geq 0.50$ sebagai cut-off value, sehingga disimpulakan kontruk untuk mengukur faktor kelemahan memiliki validitas yang baik. Kemudian hasil perhitungan dari 32 kontruk faktor kekuatan (strenght) diperoleh Construct Reliability (CR) sebagai berikut:

$$
\begin{gathered}
C R=\frac{\left(\sum \lambda_{\mathrm{j}}\right)^{2}}{\left(\sum \lambda_{\mathrm{j}}\right)^{2}+\sum \varepsilon j}=\frac{(16.01)^{2}}{(16.01)^{2}+2.13} \\
=\frac{256.32}{258.45}=0.99
\end{gathered}
$$

Construct Reliability (CR) sebesar $0.99 \geq 0.70$ sebagai cut-off value, sehingga disimpulakan kontruk untuk mengukur faktor kekuatan (strength) memiliki realibilitas yang stabil. Sedangkan untuk nilai Varian Exracted (VE) sebagai berikut:

$$
\begin{gathered}
V E=\frac{\left(\sum \lambda_{\mathrm{j}}{ }^{2}\right)}{\left(\sum \lambda_{\mathrm{j}}{ }^{2}\right)+\sum \varepsilon j}=\frac{13.41}{13.41+2.13}=\frac{13.41}{15.54} \\
=0.86
\end{gathered}
$$

Varian Exracted (VE) sebesar $0.86 \geq 0.50$ sebagai cut-off value, sehingga disimpulakan kontruk untuk mengukur faktor kekuatan memiliki validitas yang baik.

\section{Uji Hipotesis}

Hipotesis yang akan diuji adalah hipotesis berdasarkan rumusan masalah yang telah dipaparkan di atas, diperoleh nilai thitung seperti pada diagram dan persamaan struktural berikut: 


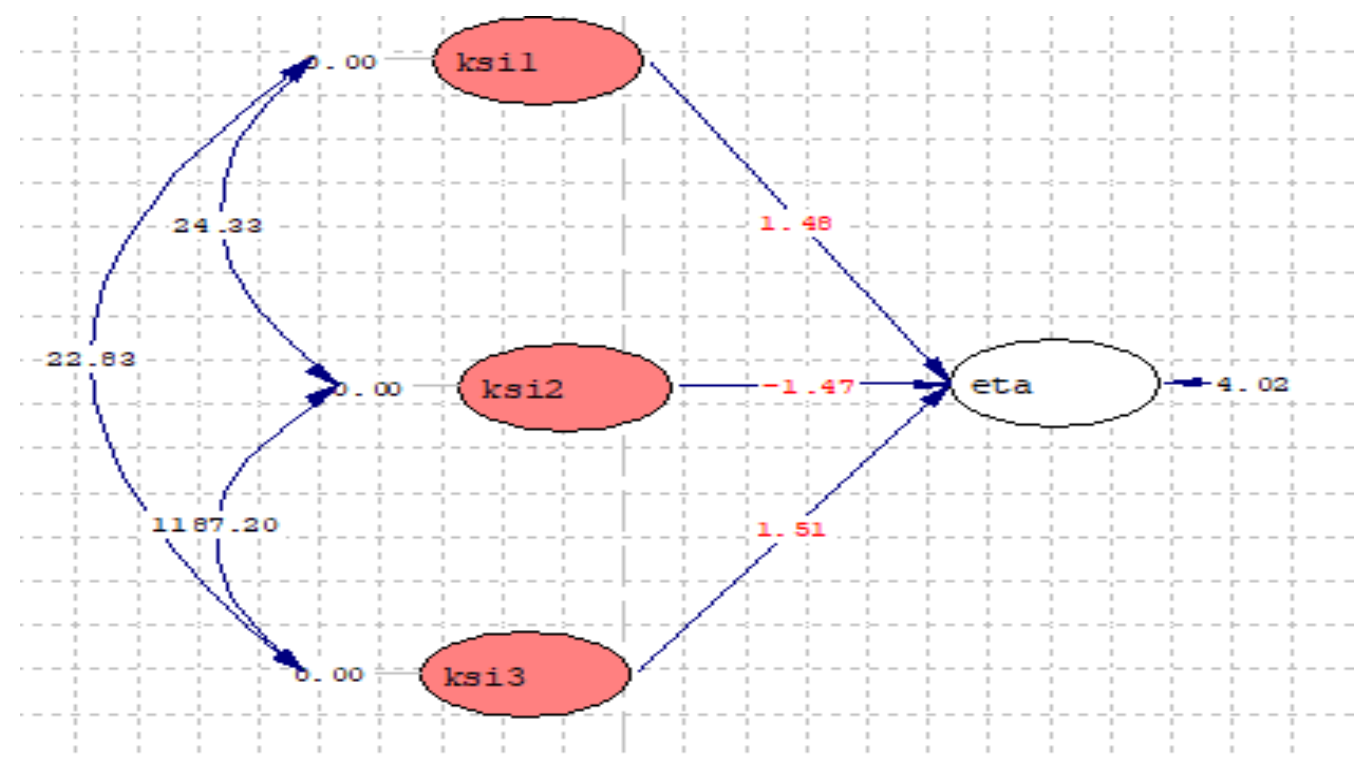

Gambar 6. Diagram Uji Hipotesis

\section{Structural Equations}

$\eta=0.67 * \xi 1-8.82 * \xi 2+8.62 * \xi 3$, Errorvar $=0.74, \mathrm{R}^{2}=$ 0.25

$\begin{array}{llll}(0.45) & (5.99) & (5.72) & (0.18) \\ 1.48 & -1.47 & 1.51 & 4.02\end{array}$

Tiga hipotesis yang akan diuji yaitu pengaruh pengalaman dosen $(\xi 1)$ motivasi dosen $(\xi 2)$ dan dukungan lembaga $(\xi 3)$ terhadap kelemahan $(\eta)$ dalam pembentukan lembaga penerbit (UMSB Press) Universitas Muhammadiyah Sumatra Barat sebagai berikut:

Terdapat pengaruh yang signifikan faktor pengalaman dosen terhadap faktor kelemahan dalam pembentukan lembaga penerbit (UMSB Press) Universitas Muhammadiyah Sumatra Barat

\section{Hipotesis statistik 1}

$\mathrm{H}_{\mathrm{O}}: \gamma 1=0$ (pengaruh tidak signifikan)

$\mathrm{H}_{1}: \gamma 1 \neq 0$ (pengaruh signifikan)

Berdasarkan hasil perhitungan diperoleh nilai $\mathrm{t}_{\text {hitung }}=1.48$ banding dengan $\mathrm{t}_{\text {tabel }} \mathrm{db}=\mathrm{n} \geq 100 \alpha 0.05=$ 1.64. $t_{\text {hitung }}=1.48 \leq 1.64$, dengan demikian Ho diterima. Artinya tidak terdapat pengaruh yang signifikan faktor pengalaman dosen terhadap faktor kelemahan dalam pembentukan lembaga penerbit (UMSB Press) Universitas Muhammadiyah Sumatra Barat

Terdapat pengaruh faktor motivasi dosen terhadap faktor kelemahan dalam pembentukan lembaga penerbit (UMSB Press) Universitas Muhammadiyah Sumatra Barat

\section{Hipotesis statistik 2}

$\mathrm{H}_{\mathrm{O}}: \gamma 2=0$ (pengaruh tidak signifikan)

$\mathrm{H}_{1}: \gamma 2 \neq 0$ (pengaruh signifikan)

Berdasarkan hasil perhitungan diperoleh nilai $\mathrm{t}_{\text {hitung }}=1.47$ banding dengan $\mathrm{t}_{\text {tabel }} \mathrm{db}=\mathrm{n} \geq 100 \alpha 0.05=$ 1.64. $t_{\text {hitung }}=1.47 \leq 1.64$, dengan demikian Ho diterima. Artinya tidak terdapat pengaruh yang signifikan faktor motivasi dosen terhadap faktor kelemahan dalam pembentukan lembaga penerbit (UMSB Press) Universitas Muhammadiyah Sumatra Barat

Terdapat pengaruh faktor dukungan lemabaga terhadap faktor kelemahan dalam pembentukan lembaga penerbit (UMSB Press) Universitas Muhammadiyah Sumatra Barat

\section{Hipotesis statistik 3}

$\mathrm{H}_{\mathrm{O}}: \gamma 3=0$ (pengaruh tidak signifikan)

$\mathrm{H}_{1}: \gamma 3 \neq 0$ (pengaruh signifikan)
Berdasarkan hasil perhitungan diperoleh nilai $\mathrm{t}_{\text {hitung }}=1.51$ banding dengan $\mathrm{t}_{\text {tabel }} \mathrm{db}=\mathrm{n} \geq 100 \alpha 0.05=1.64$. $\mathrm{t}_{\text {hitung }}=$ $1.51 \leq 1.64$, dengan demikian Ho diterima. Artinya tidak terdapat pengaruh yang signifikan faktor dukungan lembaga terhadap faktor kelemahan dalam pembentukan lembaga penerbit (UMSB Press) Universitas Muhammadiyah Sumatra Barat

\section{PENUTUP}

\section{Simpulan}

Berdasarkan Hasil analisis data diperoleh beberapa kesimpulan sebagai berikut:

1) Tidak terdapat pengaruh yang signifikan faktor pengalaman dosen terhadap faktor kelemahan dalam pembentukan lembaga penerbit (UMSB Press) Universitas Muhammadiyah Sumatra Barat

2) Tidak terdapat pengaruh yang signifikan faktor motivasi dosen terhadap faktor kelemahan dalam pembentukan lembaga penerbit (UMSB Press) Universitas Muhammadiyah Sumatra Barat

3) Tidak terdapat pengaruh yang signifikan faktor dukungan lembaga terhadap faktor kelemahan dalam pembentukan lembaga penerbit (UMSB Press) Universitas Muhammadiyah Sumatra Barat

\section{Saran}

Berdasarkan hasil temuan dan kesimpulan diatas, penulis memberikan saran sebagai berikut:

1) Pembentukan lembaga penerbit UMSB Pres bisa dilanjutkan, kelemahan dosen seperti; Kesulitan dalam menerbitkan buku, kesulitan dalam menulis buku, kesulitan dalam mencetak buku, kesulitan dalam menerbitkan / mencetak buku dan, kesulitan memasarkan buku. Semua kelemahan tersebut dapat diminimalisir atau ditekan dengan faktor kekuatan seperti, pengalaman dosen. motivasi dosen dan, dukungan lembaga (kampus). Dengan kata lain kelemahan bukan sebuah hambatan bagi UMSB dalam pembentukan lembaga penerbit.

2) Bagi peneliti seanjutnya hendak melakukan penelitian ulang karena penelitian ini masih banyak kelamahan terutama dalam instrument alat pengumpulan data, sebaiknya kedepan bila menggunakan SEM instrument yang digunakan harus berskala likert atau ordinal, agar mendapatkan data yang berkala interval.

\section{DAFTAR PUSTAKA}

Alam, S. (2018). Penentuan Strategi Bisnis Melalui Analisis Swot Pada Jaxs Barbershop di Kota Makassar. 2(3), 303-312. Retrieved from file:///C:/Users/RAHMAD

HAMID/Downloads/Jurnal sept-2017.pdf

Austin, E. (2005). Review of Latent variable models: An 
introduction to factor, path and structural analysis. British Journal of Mathematical and Statistical Psychology.

Ghozali, I. (2008). Structural equation modeling: Metode alternatif dengan partial least square (pls). Badan Penerbit Universitas Diponegoro.

Haryono, S. (2014). Mengenal Metode Structural Equation Modeling ( Sem ) Untuk Penelitian Manajemen menggunakan AMOS. Jurnal Ekonomi Dan Bisnis STIE YPN Vol. VII No. 1 Oktober 2014.

Jöreskog, K. G., \& Sörbom, D. (1989). LISREL 7: A guide to the program and applications. Spss.

Roca, J. C., Chiu, C. M., \& Martínez, F. J. (2006). Understanding e-learning continuance intention: An extension of the Technology Acceptance Model. International Journal of Human Computer Studies, 64(8), $683-696$. https://doi.org/10.1016/j.ijhcs.2006.01.003

Sugiyono. (2012). Metode Penelitian Kuantitatif, Kualitatif dan R \& D.Bandung:Alfabeta. Metode Penelitian Kuantitatif, Kualitatif Dan $R \quad \&$ D.Bandung:Alfabeta.

https://doi.org/10.1017/CBO9781107415324.004

Tamara, A. (2016). Implementasi analisis SWOT dalam strategi pemasaran produk mandiri tabungan bisnis. Jurnal Riset Bisnis Dan Manajemen, 4(3), 395-406. Retrieved from file:///C:/Users/RAHMAD S HAMID/Downloads/12751-25433-1-SM.pdf

Zia, H. K., Semiarty, R., \& Lita, R. P. (2018). ANALISIS SWOT SEBAGAI PENENTU STRATEGI PEMASARAN PADA RUMAH SAKIT GIGI DAN MULUT BAITURRAHMAH PADANG. Jurnal Kesehatan Andalas. https://doi.org/10.25077/jka.v7i0.914 